\title{
Boundaries of Upper Cretaceous hypostratotypes at the profile Djebel Fguira Salah, Tunisia
}

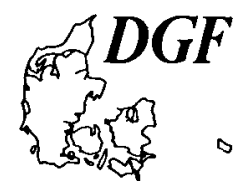

Salaj, J.: Boundaries of Upper Cretaceous hypostratotypes at the profile Djebel Fguira Salah, Tunisia.
Bull. geol. Soc. Denmark vol. $33 \mathrm{pp}, 199-2$ 01, Copenhagen, September, 11th, 1984 .
https://doi.org/10.37570/bgsd-1984-33-18
In the Upper Cretaceous section at Djebel Fguira Salah, El Fahs, Tunisia, the following stage
boundaries are defined on the basis of macro- and microfaunas: Albian-Cenomanian,
Cenomanian-Tironian, Turo-nian-Coniacian, Coniacian-Santonian, Santonian-Campanian and
Campanian-Maastrichtian.

Joseph Salaj, Dionýz Stúr Institute of Geology, Mlynska dolina 1, 81704 Bratislava, Czechoslovakia, February 3rd, 1984.

Albian-Campanian sediments of the standard profile at Djebel Fguira Salah (near Pont du Fahs, $50 \mathrm{~km} \mathrm{SW}$ of Tunis, see fig. 1) have been proposed as neostratotypes or hypostratotypes of the stages Albian, Cenomanian, Turonian, Coniacian, Santonian and Campanian respectively (Salaj 1973, 1974, 1978; Salaj; Azzouz \& Maamouri 1976; Salaj \& Bellier 1978). During the plenary discussion at the symposium on Cretaceous Stage Boundaries held in Copenhagen, October 21, 1983 it emerged that some of these units may be suitable for proposal as stratotype boundaries: i.e., the Albian-Cenomanian; ConiacianSantonian and Santonian-Campanian boundaries. In the following we define the boundaries of the individual stages as they are developed at Djebel Fguira Salah.

\section{Albian-Cenomanian boundary}

This boundary is defined by a rich ammonite fauna (Solignac 1927, p. 170, Gastany, p. 189, Salaj \& Bellier 1978, p. XXI, 2, Salaj 1980, p. 68-69). Thus, in the basal Cenomanian beds the species Neostlingoceras carcitamensis is found abundantly (samples Z-1925, 1193/11). Simultaneously, the foraminifera Thalmanninella brotzeni Sigal and Schackoina cenomana (Schacko) appear.

The detailed lithological characterization and stratigraphy of the whole Cenomanian succession was demonstrated during the Micropaleontological African Colloquium (Salaj 1974). See aerial photo in Salaj, Azzouz \& Maamouri (1976).

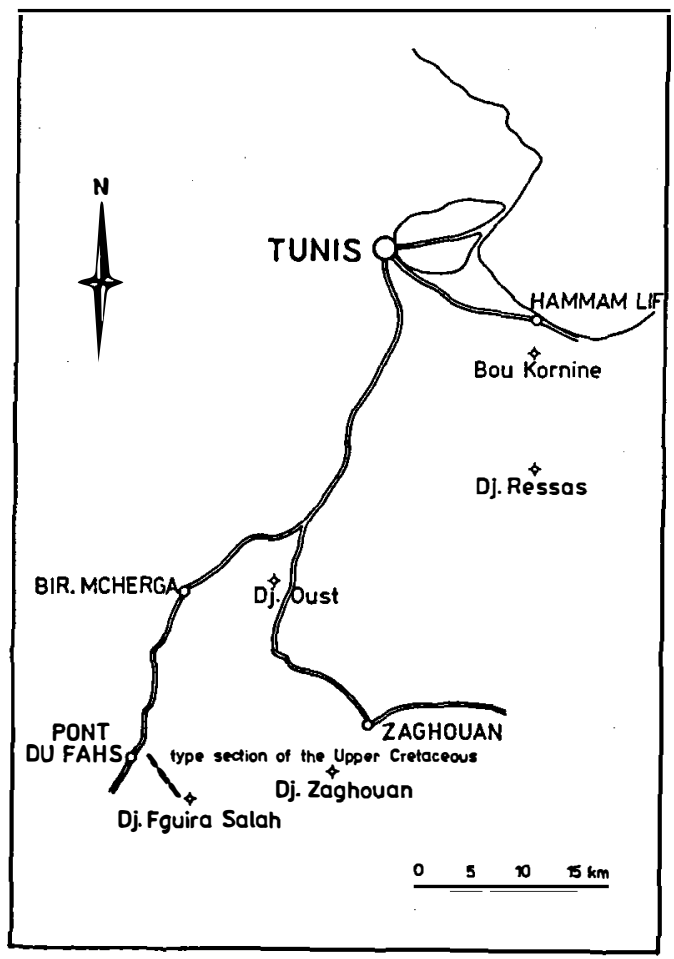

Fig. 1. Topographic situation of the Upper Cretaceous section of Ojebel fouira Salah 


\section{Cenomanian - Turonian boundary}

If the uppermost layers of the Rotalipora cushmani Zone (samples 1183 e,f,g,h) (assigned by Salaj 1980 to the basal Turonian) belong to the Cenomanian, then the base of the following zone of "larger Hedbergellas" or Whiteinella gigantea Dicarinella imbricata Zone (see Salaj \& Gašpariková 1983) would define the Turonian base (sample 120 a). In this case there would be no problem with the Cenomanian-Turonian boundary. On the basis of ammonites (Hancock 1983, Bengtson 1983) (Metoicoceras geslinianum Zone) the Cenomanian-Turonian boundary falls within the Whiteinella gigantea - Dicarinella imbricata Zone (see Wright \& Kennedy 1981, p. 125-127, Hancock 1983, p. 61). In this case it would be difficult to establish the boundary on account of condensed sedimentation (about $120 \mathrm{~cm}$ thickness) in the studied foraminifer zone. For this reason, solution of the problem of the Cenomanian-Turonian boundary on the basis of macrofauna at the profile of $\mathrm{Dj}$. Fguira Salah is unsuitable.

\section{Turonian-Coniacian boundary}

In the beds overlying the Upper Turonian with Hippurites requiemi, echinoids (Salaj \& Bellier 1978) and Marthasterites furcatus (Salaj \& Gašparikova 1983), the Upper Coniacian base (sample Z-38) is defined on the basis of foraminifera by the apperance of Dicarinella concavata (Brotzen) and Dicarinella assymetrica (Sigal). Among the macrofauna, rudists and crinoids are both found, but have not been studied in detail.

\section{Coniacian-Santonian boundary}

In the beds overlying the Upper Coniacian (samples 1302d, 1302e) (see Salaj 1980, pl. 50) with Protexanites (determination by Wiedmann, 1974), representatives of Inoceramus (Platyceramus) siccensis (Perv.) appear in limestone horizons, which unambiguously determine the Santonian base. The foraminifera Sigalia carpathica Salaj \& Samuel also appears. About $10 \mathrm{~m}$ higher up, representatives of the species Texanites oliveti appear (between samples 2007-2008, determination and finds by Wiedmann, Kennedy).

\section{Santonian-Campanian boundary}

This is determined by appearance of the species Globotruncana arca (Cushman) (foraminifera) and Aspidolithus parcus (Stradner) (nannoplankton). These species are found in beds overlying the Upper Santonian proved by a rich fauna of ammonites and rudists (Wiedmann, in Salaj 1980, p. 92, fig. 31).

\section{Campanian-Maastrichtian boundary}

The Maastrichtian base is determined by the appearance of the species Globotruncana falsostuarti Sigal. However, taking into account the condensed nature of the sedimentation at the Campanian-Maastrichtian boundary, this section is not suitable for resolving the question of the Campanian-Maastrichtian boundary. For the solution of the Campanian-Maastrichtian boundary problem as well as of Campanian-Maastrichtian stratigraphy in Tunisia, the area of El Kef is most suitable (Kat ez Zerblia \& El Haria, see Salaj \& Maamouri, 1983).

\section{Dansk sammendrag}

I et profil ved El Fahs, Tunis, er følgende øvre kridt etagegrænser defineret på basis af makro- og mikrofossiler: albiencenomanien, cenomanien-turonien, turonien-coniacien, coniacien-santonien, santonien-campanien og campanien-maastrichtien.

\section{References}

Bengtson, P. 1983: The Cenomanian-Turonian succession of Sergipe Brazil and the question of the stage boundaries. Symposium on Cretaceous Stage Boundaries, Copenhagen. Abstracts, 13-16.

Castany, G. 1951: Étude géologique de l'Atlas tunisien oriental. Ann. Mines et Géol. Tunis, 8, 1-632.

Hancock, J. M. 1983: Principles and some proposals for the definition of states in the Upper Cretaceous. Symposium on Cretaceous Stage Boundaries, Copenhagen. Abstracts, $59-62$. 
Hancock, J. M. \& Kennedy, W. J. 1981: Upper Cretaceous ammonite stratigraphy: some current problems. In HOUSE, R. M. \& SENIOR, J. R. (eds.) The Ammonoidea. Spec. Vol. Systematics Ass. 18, 531-553.

Salaj, J. 1973: Proposition pour les Néostratotypes du Crétacé supérieur (en vue de la zonation des regions de la Téthys). Ann. Mines et Géol. Tunis 26, 219-222.

Salaj, J. 1974: Microbiostratigraphie du Crétacé supérieur de la région de Pont du Fahs. Livret-guide des excursion-VIe Coll. Afr. Micropaléont. Tunis, 41-49.

Salaj, J. 1980: Microbiostratigraphie du Crétacé et du Paleogéne de la Tunisie septentrionale et orientale (Hypostratotypes tunisiens). Ed. Inst. Géologique de D. Stúr, Bratislava, 1-232.

Salaj, J. \& Bellier, J. P. 1978: Une coupe de reférence pour la zonation de l'Albien, du Cénomanien et du Turonien de Tunisie septentrionale. Ann. Mus. Hist. Nice 4 (21), 1-21, 10.
Salaj, J. Azzouz, A. \& Maamouri, A. L. (in press): Les hypostratotypes tunisiens du Crétacé supérieur et du Paléocene. Actes di VII Coll. Afr. Micropalont. ILE-IFE 1976.

Salaj, J. \& Gašpariková, V. 1983: Turonian and Coniacian microbiostratigraphy of the Tethys regions on the basis of Foraminifera and nannofossils. Zitteliana 10, 595-607.

Salaj, J. \& Maamouri, A. L. 1983: Campanian-Maastrichtian boundary in the Tethyan region based on planktonic foraminifers (Kat ez Zerbia-El Haria and Djebel Fguira Salah, Tunisia). Symposium on Cretaceous Stage Boundaries, Copenhagen. Abstracts, 178-181.

Solignac, M. 1927: Étude géologique de la Tunisie septentrionale. Mém. Carte géol. Tunisie, Tunis, 1-756.

Wright, C. W. \& Kennedy, W. J. 1981: The Ammonoidea of the Plenus Marls and the Middle Chalk. Monogr. Paleontogr. Soc., 1-148. 